Article

\title{
Effects of Land Certification for Rural Farm Households in Ethiopia: Evidence from Gozamin District, Ethiopia
}

\author{
Abebaw Andarge Gedefaw ${ }^{1,2}{ }^{\mathbb{D}}$, Clement Atzberger ${ }^{1}\left(\mathbb{D}\right.$, Walter Seher $^{3} \mathbb{D}$, \\ Sayeh Kassaw Agegnehu ${ }^{2}$ and Reinfried Mansberger 1,*(D) \\ 1 Institute of Geomatics, University of Natural Resources and Life Sciences Vienna (BOKU), \\ Peter Jordan-Strasse 82, 1190 Vienna, Austria; abebaw.gedefaw@students.boku.ac.at (A.A.G.); \\ clement.atzberger@boku.ac.at (C.A.) \\ 2 Institute of Land Administration, Debre Markos University (DMU), Debre Markos 269, Ethiopia; \\ sayeh_kassaw@dmu.edu.et \\ 3 Institute of Spatial Planning, Environmental Planning and Land Rearrangement, University of Natural \\ Resources and Life Sciences Vienna (BOKU), Peter Jordan-Strasse 82, 1190 Vienna, Austria; \\ walter.seher@boku.ac.at \\ * Correspondence: mansberger@boku.ac.at
}

Received: 28 September 2020; Accepted: 28 October 2020; Published: 30 October 2020

\begin{abstract}
Economic theory notes tenure security is a critical factor in agricultural investment and productivity. Therefore, several African countries' development initiatives enabled land titling to enhance tenure security. This paper examines the effect of land certification on tenure security, land investment, crop productivity and land dispute in Gozamin District, Ethiopia. In addition, the impact of land certification on farm households' perceptions and confidence in land tenure and land use rights is investigated. Face-to-face interviews with 343 randomly selected farm households, group discussions and expert panels are the sources of primary data. Quantitative data are analyzed using various statistical tools and complemented by qualitative data. According to the results, most farm households (56\%) feel that their land use rights are secure after the certification process. Only $17 \%$ fear that the government at any time could take their land use rights. The majority of farm households $(71.7 \%)$ identified a reduction of disputes after certification and land management practices improved from $70.3 \%$ before certification to $90.1 \%$ after certification. As key factors for the increase of terracing and the application of manure, the study determined total farm size, the average distance from farm to homestead, perception of degradation, access to credit, training to land resource management, fear about land take-over by the government and total livestock holdings. Crop productivity improved significantly after land certification. The results should encourage policy makers to minimize the sources of insecurity, such as frustrations of future land redistribution and land taking without proper land compensation. Land certification is the right tool for creating tenure security, enhancing farmers' confidence in their land rights and — supported by a proper land use planning system-improving land-related investments and crop productivity.
\end{abstract}

Keywords: boundary conflict; land certification; land investment; manure use; perceived tenure security; terracing

\section{Introduction}

As land is a vital resource in Africa, land reform is a key development effort [1,2]. Reliable access to land as a productive resource is vital to the livelihoods of millions of farm households around the globe $[3,4]$. In several developing countries, the formalization of land rights through land certification 
has advocated the highest importance in their economic development programs [5-9]. Studies have shown that land certification improves the sense of tenure security and land rights, reduces land disputes and enhances farmers' investment in land and agricultural productivity [10-23].

Land tenure security and land tenure rights are identified as key determinants of land use and investments in land improvement. They provide incentives to conserve land quality, to reinforce private incentives for long-term investment in soil conservation and to intensify agriculture [21,22]. Where individual farmland rights on agricultural land are recognized, farmers are investing in long-term improvements, including crop rotation, manure, soil conservation and tree planting [23-25]. Farmers are now growing trees on the edge of crops in East Africa, because they have acquired the right of individuals to secure land use [23]. Farmers holding land under precarious conditions are less likely to invest in long-term investments such as building soil and water conservation structures and tree planting [26]. In addition, tenure security is important for social, environmental and economic development and it is essential to alleviating inaccessible investments, credit opportunities, unsafe shelter, short-term exploitation of resources and mismanagement [27]. However, there are also cases where tenure security had no impact on investment in land management [28-30].

Titling by land registration is widely believed to improve land use and agricultural production efficiency by increasing incentives for farmers to adopt new technologies, on-farm investment and land conservation practices [31,32]. The Ethiopian government strengthens land tenure security with the aim to encourage farmers for technical investments to reduce erosion and to enhance land quality [33]. Insecurity of land rights has had in the past a variety of negative consequences, affecting the social and economic well-being of farmers. Key indicators of tenure insecurity include poor performance in the agricultural sector, no incentive for land investment, legally impossible land rights for women, no rental market and increased land related disputes [34].

Land issues have a strong impact on a wide range of issues and policy concerns, including agricultural development, management of resources, poverty reduction, food security and human rights $[31,35,36]$. Land is very important to the livelihoods, income and employment of the majority of the population. Land is more than a factor of production-it is a source of political power, a foundation for complex alliances and reciprocity relations and an integral part of social identity.

Therefore, the land administration system in Ethiopia has been at the forefront of policy debates for generations [37]. Land was concentrated in the hands of the absentee landlords for decades during the imperial period, and arbitrary evictions posed a significant threat to tenant farmers [24]. Following the overthrow of the imperial regime by a military coup, the Derg government introduced reforms that changed the agrarian system and access to land, shifting land ownership to the state [9]. Since the collapse of the Derg dictatorship in 1991, the new government started to liberalize the economy. However, the set of reforms largely neglected the land problem, and the Derg legacy continued to define key elements of the current land policy [37]. The current government neglected privatization of land, maintaining a discourse of social equity and avoiding the danger of land concentration in the hands of a few. Nevertheless, the government stalled the frequency of land redistribution and officially enabled land rentals [37].

The Amhara National Regional State (ANRS) carried out major land redistributions in 1997. Following this, the impact of such redistribution has been hotly debated in Ethiopia. Land redistribution is believed to erode tenure security, which has prevented farmers from investing in land improvement [38]. As a result, this fragmentation and reallocation of land holdings is believed to have a negative impact on land management activities [38].

Especially in an effort to counter these shortcomings and to strengthen farmers' tenure security, the Ethiopian government initiated and launched a large-scale land registration and certification program in 1998 [37] with the aim to improve tenure security in order to encourage sustainable land use, to increase land-related investments and to reduce land conflicts [39]. The land certification program was introduced in four regions of the country: Tigray, Amhara, Oromia and the Southern Nations and Nationalities (SNNP). Currently, more than $90 \%$ of farming households have received certificates, 
which includes the rights and obligations on the land, the names of land holders, the size as well as the location and soil quality of farm plots $[40,41]$. In particular, a pilot land certification program started in 2002 and scaled up in 2003 in the Amhara National Regional state (ANRS). Hence, in the Revised Rural Land Administration and Use Determination of the Amhara National Regional State document under proclamation No. 252/2017, Article 13, it is stressed that in any part of the region, land redistribution and allotment shall not be carried out, unless it is used for irrigation land to users [42].

In general, there is a lack of knowledge about the effects of land certification on tenure security, on land investment and on land disputes in the Gozamin district. The key objective of this study is to fill this knowledge gap by investigating the effects of rural land certification on farm households in the Ethiopian Gozamin district.

To achieve this objective, the following research questions were defined:

1. Did rural land certification improve the sense of tenure security of farm households?

2. Did land certification reduce the number of land disputes in the study area?

3. Was there a change of crop productivity after the certification process?

4. Did land certification influence agricultural intensifications such as terracing and the use of manure. If yes, what were the factors of influence?

\section{Materials and Methods}

\subsection{Description of Study Area}

Gozamin district (Figure 1) was purposively selected for this study based on the following criteria:

- The existence of second level land certification documents for farm households; (in Gozamin district, all farm households received the document of completion of second level land certification);

- It was the first pilot site for the second land certification process (mapping of parcels);

- There were a variety of agro-climatic zones, leading to different types of crop farming practices;

- $\quad$ Local knowledge of authors for the study site.
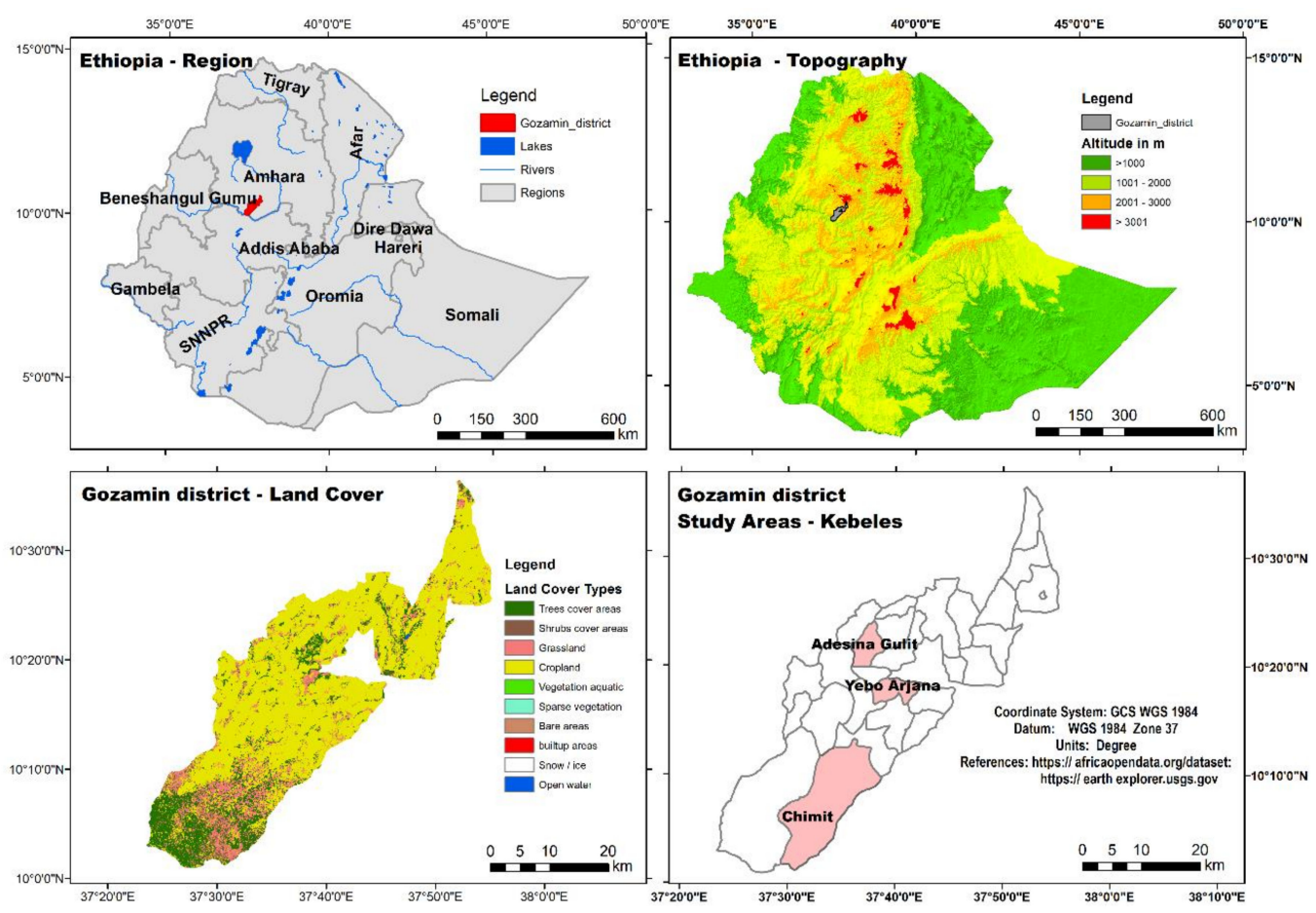

Figure 1. Gozamin District, Ethiopia—the study area (Adapted from Gedefaw et al., 2019 [43]). 
Gozamin district is located $270 \mathrm{~km}$ east of the regional capital Bahir Dar, Amhara National Regional State, and $300 \mathrm{~km}$ northwest from Addis Ababa. The district has a total area of $1218 \mathrm{~km}^{2}$, 134,000 inhabitants, and contains in total 25 rural kebeles (lowest administrative level in Ethiopia). Its elevation ranges from $\sim 1000 \mathrm{~m}$ to $\sim 3200 \mathrm{~m}$ above sea level. Annual rainfall ranges from about $1000 \mathrm{~mm}$ to $1510 \mathrm{~mm}$ per year. The average minimum temperature is $8.5^{\circ} \mathrm{C}$ and the maximum temperature reaches $30^{\circ} \mathrm{C}$. The district is characterized by a relatively flat landscape, flood plains and wetlands. Sedentary, rainfed, small-scale agriculture and livestock rearing are the major sources of livelihood within the Gozamin district. People primarily perform mixed cereal agriculture, with farmers growing teff, finger millet, sorghum, maize, barley, wheat, pulses, oil crops, vegetables and fruits $[43,44]$. Due to the high anthropogenic influence in the study area, native forests have been lost. Remnant plants around holy places, inaccessible areas, left for shade trees and on grazing lands are observed.

\subsection{Methodology}

\subsubsection{Selection of Sample Kebeles and Farming Households}

Among the 25 Kebeles found in the district, three kebeles, Chimit, Yebona-Erjena and AddisnaGuilit, were selected for the primary data collection applying the same criteria as for the selection of the district. The sample size of farm households was determined on the basis of the sample size determination equation by Cochran [45]. Out of the 3277 farm households in the three selected kebeles (Table 1), 343 farm households were randomly sampled for interview (115 from Chimit, 131 from Yebona-Erjena, and 97 from Addisna-Guilit). The number of farm households selected for interview from each kebele was determined proportional to the total number of farm households in the kebele (rounded to integer) to guarantee an equal representation of farm households in each kebele. The detailed information about the total farm households and samples is documented in Table 1.

Table 1. Number of total farm households and sample farm households in the study area.

\begin{tabular}{ccc}
\hline Name of Kebele & Total Farm Households & Sampled Farm Households \\
\hline Chimit & 1100 & 115 \\
Yebona-Erjena & 1250 & 131 \\
Addisna-Guilit & 927 & 97 \\
\hline Total & 3277 & 343 \\
\hline
\end{tabular}

Sample farm households were selected using the systematic random sampling technique. Sampling frames were obtained for each kebele by taking the list of all farm households in alphabetical order from the respective kebele administration offices. The sample farm households were drawn from each administrative unit from the list of names after a certain sampling interval $(\mathrm{K})$ that was determined by dividing the total number of farm households by the predetermined sample size of each kebele. Next, a number was selected between one and the sampling interval $(\mathrm{K})$ using the lottery method (called the random start) and was used as the first number included in the sample. Then, every $K^{\text {th }}$ farm household head after that first random start was taken until reaching the desired sample size for each kebele administration. Systematic sampling was applied because sample units are uniformly distributed over the population [46]. In total, data of 343 farm households were encoded using Statistical Package for Social Science (SPSS, version 24), and the analyses were performed with the " $\mathrm{R}$ " software by importing the data from SPSS.

\subsubsection{Data Collection Techniques}

Key primary data were collected in a comprehensive household survey conducted between September 2018 and December 2018 with a set of structured questionnaires. For the household survey, both closed and open-ended questionnaires were developed. Farming households were asked about their perceptions of landholding rights, land conflicts and land management activities before and 
after certification. Face-to-face interviews were needed, as many of the respondents were expected to be illiterate. To avoid language difficulties, the questionnaires were translated from English to Amharic (local language). Six experts with a minimum college diploma in related fields of land administration collected the data. Before data collection, they were trained to guarantee a standardized and harmonized data collection procedure. A pre-testing of the questionnaires was conducted in advance in one of the studied kebeles, at Addisna-Guilit Kebele, for four days. Based on these experiences, the questionnaires were adapted and improved. Specifically, questionnaires were used to collect information on socio-economic characteristics of the farming households, perceptions of land holding rights, land conflicts and land management activities before and after certification.

All factors identified in the household survey are documented in Table 2.

Table 2. Description of the variables used in the study.

\begin{tabular}{|c|c|}
\hline Description (Variable Name) & Values of Variables \\
\hline Type of household heading-TYH & $=1$ joint,$=0$ otherwise \\
\hline Sex of household head-SEH & $=1$ female $=0$ male \\
\hline Age of household head-AGH (in years) & $=0,1,2,3, \ldots, \mathrm{n}$ \\
\hline Educational level of household head-EDH & $=1$ literate, $=0$ illiterate \\
\hline Total size of household-TSH (in numbers of persons) & $=0,1,2,3, \ldots, n$ \\
\hline $\begin{array}{l}\text { Total farm size-TFS (in hectare) (before certification-TFSBC; } \\
\text { after certification-TFSAC) }\end{array}$ & $=0,1,2,3, \ldots, \mathrm{n}$ \\
\hline Average distance from farm to homestead-ADFH (in minutes) & $=0,1,2,3 \ldots, \mathrm{n}$ \\
\hline Affected by land redistribution of 1997-ALD & $=1$ yes,$=0$ no \\
\hline $\begin{array}{l}\text { Fear of loss of land due to the expropriation by government at } \\
\text { any time-FLG }\end{array}$ & $=1$ yes, $=0$ no \\
\hline $\begin{array}{l}\text { Fear of loss of farmland due to redistribution within the next five } \\
\text { years-FLF }\end{array}$ & $=1$ (do not fear) yes, $=0$ otherwise \\
\hline $\begin{array}{l}\text { Perception about degradation (before certification-DBC; after } \\
\text { certification-DAC) }\end{array}$ & $=1$ yes,$=0$ no \\
\hline $\begin{array}{l}\text { Access to credit (before certification-ACBC; after } \\
\text { certification-ACAC) }\end{array}$ & $=1$ yes, $=0$ no \\
\hline $\begin{array}{l}\text { Land resource management training available (before } \\
\text { certification-TBC; and after certification-TAC) }\end{array}$ & $=1$ yes, $=0$ no \\
\hline $\begin{array}{l}\text { Total livestock of farming household (before certification-LSBC; } \\
\text { after certification -LSAC) }\end{array}$ & $=0,1,2,3, \ldots, \mathrm{n}$ (in tropical livestock units) \\
\hline $\begin{array}{l}\text { Application of land cultivation practices of parcel (before } \\
\text { certification-LMBC; after certification-LMAC) }\end{array}$ & $=1$ yes, $=0$ no \\
\hline $\begin{array}{l}\text { Terracing of parcels (before certification-TEAC; after } \\
\text { certification-TEBC) }\end{array}$ & $=1$ yes, $=0$ no \\
\hline $\begin{array}{l}\text { Manure use (before certification-MBC; after } \\
\text { certification-MAC) }\end{array}$ & $=1$ yes, $=0$ no \\
\hline $\begin{array}{l}\text { Compost use (before certification-CBC; after } \\
\text { certification-CAC) }\end{array}$ & $=1$ yes,$=0$ no \\
\hline $\begin{array}{l}\text { Perception about change of number of land conflicts (during } \\
\text { certification-SLCD; after certification-SLCA) }\end{array}$ & $=1$ less conflict $;=2$ no conflict,$=3$ more conflicts \\
\hline $\begin{array}{l}\text { Crop yields for various crop types in the years } 2005 \text { (before } \\
\text { certification) and } 2018 \text { (after certification) }\end{array}$ & $=0,1,2,3, \ldots, \mathrm{n}$ (in quintal) \\
\hline
\end{tabular}

In each kebele, focus group discussions (FGD) and key informant interviews were conducted to complement the survey with qualitative data. Focus group discussion participants were selected based on their knowledge and experience in Land administration practices. They have been living in the kebeles for a long time and were members of the Land Administration and Certification Committee in the kebele (LACC). The LACC is a group of persons representing different social groups in the 
community, e.g., elders, female-headed households, youths, persons with disabilities, development agents and kebele managers. In total, nine group discussions (three in each kebele) were carried out with 10 to 12 participants each. The discussion focused on perception and confidence of farm household's tenure security, land investment, land dispute, benefits of land certification and related issues.

Panels and discussion forums were organized with a total of six federal, seven regional, ten zonal and five district experts. These experts are employed in rural land administration and land use offices or in other related fields. The discussions focused on the achievements, bottlenecks and recommendations on land related investment, tenure security and land dispute.

Secondary data were gained by reviewing reports at district, zonal and federal level on the objectives of land registration and certification and related issues.

\subsubsection{Data Analysis Techniques}

Data were analyzed using methods of quantitative analysis. The analysis was complemented by a qualitative analysis of data gained in focus group discussions and key informant interviews.

Descriptive statistics were applied to describe the socio-economic characteristics by percentages, mean and standard deviation.

A binary logit regression model was used for a more detailed data analysis. For selected variables, the impact of other factors were determined by the following formula:

$$
\ln \left[\frac{P_{x}}{\left(1-P_{x}\right)}\right]=\sum_{i=1}^{n} \beta_{i} X_{i}+U_{i}
$$

where $P_{x}$ is the probability for an observed set of variables that the event occurs, $\beta_{i}$ is the $i$ th coefficient to be estimated, $X_{i}$ is the $i$ th explanatory variable and $U_{i}$ is a random error term.

Specification of the Model

Selected continuous and discrete variables were checked for multi-collinearity and association. To detect multi-collinearity between continuous variables, the variance inflation factor (VIF) technique was applied [47]. A contingency coefficient test was carried out to evaluate associations between dummy variables (binary variables). Based on the results of these tests, variables found to be highly correlated and/or associated with one or more of the other continuous or discrete variables (VIF > 10) were excluded from further analysis.

\section{Description of the Dependent Variables Used for the Study}

Names of all Variables are in Table 2. The level of perceived tenure security is indicated by the dependent variable FLF, which indicates whether farm households expect to lose farmland by redistribution within the next five years. This binary variable takes a value of 1 for farm households that do not expect redistribution in the future and 0 otherwise. The following model was used to assess the effect of land certification on perceived tenure security:

$$
\mathrm{FLF}=\beta_{0}+\beta_{1} \mathrm{TYH}+\beta_{2} \mathrm{SEH}+\beta_{3} \mathrm{AGH}+\beta_{4} \mathrm{EDH}+\beta_{5} \mathrm{TSH}+\beta_{6} \mathrm{TFS}+\beta_{7} \mathrm{ALD}+\beta_{8} \mathrm{FLG}+\beta_{9} \mathrm{LSAS}+U_{i}
$$

TEBC and TEAC assess the level of terracing of parcels by farming household before and after certification:

$$
\begin{aligned}
\text { TEBC } & =\beta_{0}+\beta_{1} \text { TFSBC }+\beta_{2} \text { ADFH }+\beta_{3} \text { DBC }+\beta_{4} \text { ACBC }+\beta_{5} \text { TBC }+\beta_{6} \text { FLG }+\beta_{7} \text { LSBC }+U_{i} \\
\text { TEAC } & =\beta_{0}+\beta_{1} \text { TFSAC }+\beta_{2} \text { ADFH }+\beta_{3} \text { DAC }+\beta_{4} \text { ACAC }+\beta_{5} \text { TAC }+\beta_{6} \text { FLG }+\beta_{7} \text { LSAC }+U_{i}
\end{aligned}
$$

where ADFH is the Average distance from farm to homestead. 
MANURE indicates investment related to land to assess the effect of land certification on manuring of parcels by farming household before and after certification:

$$
\begin{aligned}
\mathrm{MBC} & =\beta_{0}+\beta_{1} \mathrm{TFSBC}+\beta_{2} \mathrm{ADFH}+\beta_{3} \mathrm{DBC}+\beta_{4} \mathrm{ACBC}+\beta_{5} \mathrm{TBC}+\beta_{6} \mathrm{FLG}+\beta_{7} \mathrm{LSBC}+U_{i} \\
\mathrm{MAC} & =\beta_{0}+\beta_{1} \mathrm{TFSAC}+\beta_{2} \mathrm{ADFH}+\beta_{3} \mathrm{DAC}+\beta_{4} \mathrm{ACAC}+\beta_{5} \mathrm{TAC}+\beta_{6} \mathrm{FLG}+\beta_{7} \mathrm{LSAC}+U_{i}
\end{aligned}
$$

$\mathrm{ADFH}$ is the same before and after certification as farm plots only change size not site.

\section{Results}

\subsection{Characteristic of Household Heads and Farms}

Table 3 documents that for $26.8 \%$ of the sampled farm households the land certificates are issued to female persons, $12.5 \%$ of the certificates are for male persons and $60.7 \%$ of all investigated farm households got a joint issued certificate (male and female). As for the educational background of these sampled farm household heads, $54.8 \%$ was illiterate and $45.2 \%$ literate. From the literate farm household heads, $36.8 \%$ was female.

Table 3. Summary of land holding right household heads and educational level of sampled farming households.

\begin{tabular}{ccc}
\hline Variable Name & Number & Percent \\
\hline Land title household heads & & \\
Female & 92 & 26.8 \\
Male & 43 & 12.5 \\
Joint (female and male) & 208 & 60.7 \\
Total & 343 & 100 \\
\hline Educational level & & \\
Illiterate & 188 & 54.8 \\
Literate & 155 & 45.2 \\
(Female) & $(57)$ & $(36.8)$ \\
(Male) & $(98)$ & $(63.2)$ \\
Total & 343 & 100 \\
\hline
\end{tabular}

A more in-depth investigation (Table 4) into the age structure of farm household heads provided evidence that the average age was 48 years. The average household farm size was 1.29 hectares before certification and 1.27 hectares after certification. Moreover, the average family size was 6.3 persons.

Table 4. Summary statistics of continuous variables used in the logit model. BC: before certification;

\begin{tabular}{|c|c|c|c|c|c|}
\hline Variable Name & $\begin{array}{c}\text { Measurement } \\
\text { Unit }\end{array}$ & $\begin{array}{l}\text { Minimum } \\
\text { Value }\end{array}$ & $\begin{array}{c}\text { Maximum } \\
\text { Value }\end{array}$ & $\begin{array}{l}\text { Mean } \\
\text { Value }\end{array}$ & $\begin{array}{l}\text { Standard } \\
\text { Deviation }\end{array}$ \\
\hline Age of household head & Years & 24 & 75 & 48.7 & 10.80 \\
\hline Total landholding size: BC & Hectares & 0.13 & 4.50 & 1.29 & 0.65 \\
\hline Total landholding size: AC & Hectares & 0.25 & 3.50 & 1.27 & 0.62 \\
\hline Total household size & Number & 1 & 11 & 6.3 & 2.33 \\
\hline Total livestock size: BC & TLU & 0.01 & 10.5 & 3.7 & 2.46 \\
\hline Total livestock size: AC & TLU & 0.10 & 16.5 & 3.9 & 2.59 \\
\hline Average distance farm to homestead & Walk in Minutes & 5 & 40 & 14.5 & 9.14 \\
\hline
\end{tabular}
AC: after certification; TLU: Tropical Livestock Units.

The main types of livestock kept in the study district were cattle, sheep, chicken, donkey and horse. Before certification, the mean livestock size was 3.7 TLU (Tropical Livestock Units) and after certification, the mean livestock size was 3.9 TLU. The distance of the farm from the homestead was estimated by the time (in minutes) the respondent took to walk from the farm to the homestead. 
The distance is an important variable, as it effects the management of land. The average distance was $14.5 \mathrm{~min}$.

\subsection{Benefits of Land Certification}

Figure 2 documents the opinion of household heads about potential benefits of land registration and certification. In total, $95.6 \%$ of farming households believe that land certification promoted gender-balance; $92.1 \%$ mentioned the enabled inheritance of land as a benefit of the certification process. According to the Revised Rural Land Administration and Use Draft proclamation, landholding farmers have access loans from financial institutions using their land as collateral [48]; in this regard, 88.0\% of farming households perceive that certification enables them to use land as collateral. $87.5 \%$ of the household heads believe that land certification will guarantee an appropriate compensation when their land is expropriated for public purposes. The facility of land rent and share cropping (86.3\%), secured land use rights $(81.9 \%)$, improved investment in land $(77.8 \%)$ and reduction of boundary trespassing disputes $(72.6 \%)$ are also recognized as benefits by the heads of households.

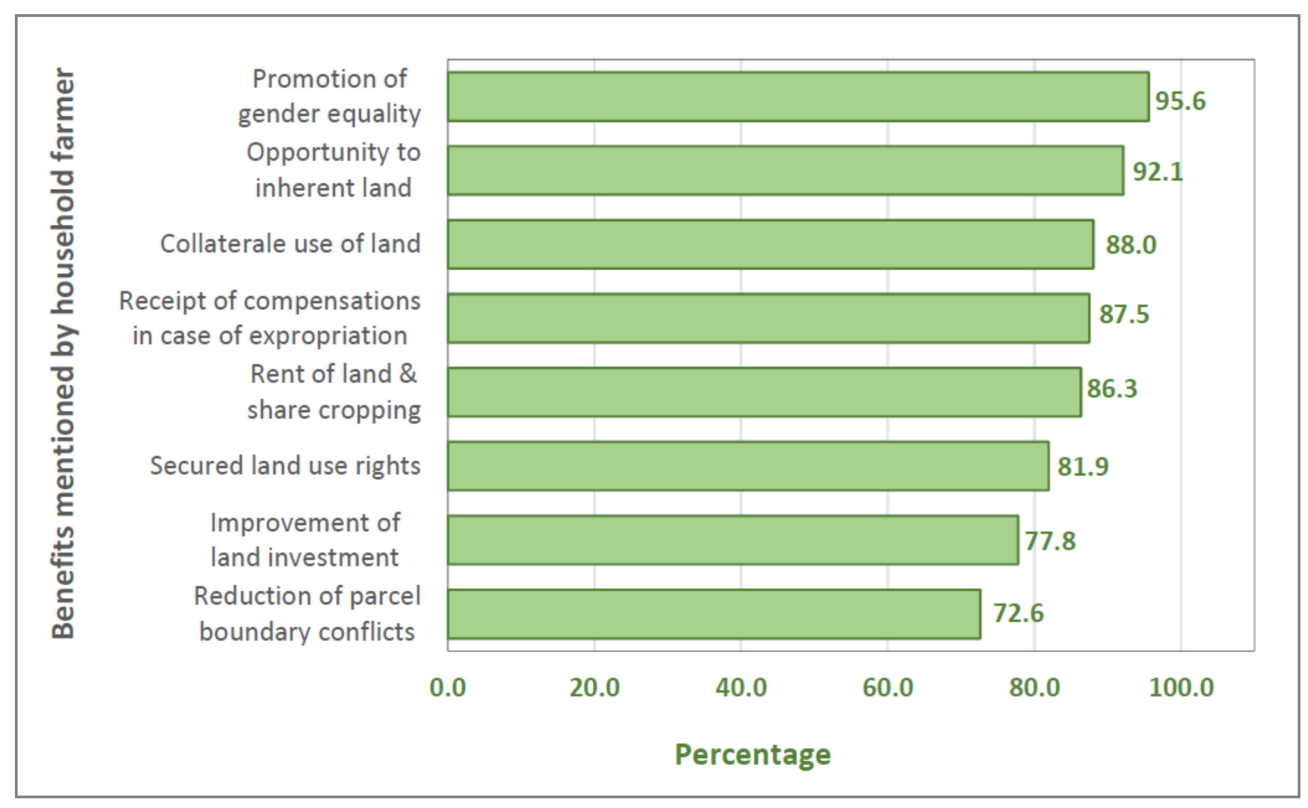

Figure 2. Benefits of Land Certification as perceived by farm households ( 343 farming households).

\subsection{Perception Concerning Confidence about Land Redistribution after Certification}

As can be seen from Table 5, farming households were asked whether they fear land redistribution beyond the next five years. $85.4 \%$ of farming households have no fears on this. Most of the household farmers $(82.2 \%)$ have no fear of expropriation of land by the government at any time. Only $17.8 \%$ replied that expropriation by the government might occur at any time. $81.6 \%$ of farming households are confident that there will be no redistribution of land over the next five years (Table 5). Accordingly, $43.4 \%$ of farming households were affected by the redistribution of land in 1997 . From these, some farming households experienced positive effects (53.5\%) as they acquired land, while $46.5 \%$ of the households suffered from losses of farmland.

There are significant differences in the perceptions of farming households as shown by Pearson's chi-square results. They differ significantly on the effect of fear of redistribution of land beyond the next five years $\left(X^{2}=31.89, p<0.001\right)$, expropriation of their land by the government at any time $\left(X^{2}=16.33\right.$, $p<0.01)$, expected redistribution over the next five years $\left(X^{2}=9.71, p<0.01\right)$ and redistribution of land in $1997\left(\mathrm{X}^{2}=7.34, p<0.01\right)$. 
Table 5. Household farmers' perception and confidence about land redistribution after land certification.

\begin{tabular}{lccccc}
\hline \multirow{2}{*}{ Variable } & \multicolumn{2}{c}{ No } & \multicolumn{2}{c}{ Yes } & \multirow{2}{*}{$\begin{array}{c}\text { Chi-Square } \\
\left(\mathbf{X}^{2}\right)\end{array}$} \\
\cline { 2 - 5 } & Number & $\%$ & Number & $\%$ & $31.89 * * *$ \\
\hline $\begin{array}{l}\text { Fear of redistribution of land } \\
\text { beyond the next five years }\end{array}$ & 293 & 85.4 & 50 & 14.6 & $16.33^{* *}$ \\
\hline $\begin{array}{l}\text { Fear of expropriation of land } \\
\text { by the government at any time }\end{array}$ & 282 & 82.2 & 61 & 17.8 & $7.71^{* * *}$ \\
\hline $\begin{array}{l}\text { Fear of redistribution of land } \\
\text { within the next five years }\end{array}$ & 280 & 81.6 & 63 & 18.4 & $7.34^{* * *}$ \\
\hline $\begin{array}{l}\text { Households affected in 1997 } \\
\text { land redistribution }\end{array}$ & 194 & 56.6 & 149 & 43.4 & \\
\hline
\end{tabular}

$* * *, * *$ Significant at $p<0.001$ and $p<0.01$ probability levels; Number of cases $=343$.

\subsection{Effect of Land Certification on Land-Related Conflicts}

Table 6 refers to the perception about the number of land-related conflicts before and after certification. The majority (60.4\%) of farm households indicated that the number of disputes before certification was higher than afterwards, while $27.4 \%$ and $12.2 \%$ perceived no change and fewer conflicts. After the certification process, the perception about the reduced number of conflicts increased; $71.7 \%$ indicated a reduction in conflicts, $19.8 \%$ no change and $8.5 \%$ increased conflicts.

Table 6. Perception of land-related conflicts before and after the land certification $(\mathrm{N}=343)$.

\begin{tabular}{ccccc}
\hline \multirow{2}{*}{ Conflicts } & \multicolumn{2}{c}{ Before Land Certification } & \multicolumn{2}{c}{ After Land Certification } \\
\cline { 2 - 5 } & Number & Percent & Number & Percent \\
\hline Fewer & 42 & 12.2 & 246 & 71.7 \\
No effect & 94 & 27.4 & 68 & 19.8 \\
More & 207 & 60.4 & 29 & 8.5 \\
\hline
\end{tabular}

\subsection{Effect of Land Certification on Land Management Practices and Crop Yield}

The main types of land management practices of farming households are terracing, the use of manure and composting.

Table 7 documents that $70.3 \%$ farm households applied at least one type of land management practice before land certification. This number changed to $90.1 \%$ after the certification process, which means a significant increase as shown in the chi-square test $\left(X^{2}=40.34, p<0.001\right)$. Terracing application was carried out by $67.9 \%$ before and $81.6 \%$ after certification. Similar figures can be seen in the use of manure practiced by farm households $70.6 \%$ before and $84.8 \%$ after certification and in composting with an increase from $58 \%$ to $78.1 \%$.

Table 7. Types of land management practices before and after certification.

\begin{tabular}{|c|c|c|c|c|c|}
\hline \multirow{2}{*}{ Variables } & \multicolumn{2}{|c|}{ Before Land Certification } & \multicolumn{2}{|c|}{ After Land Certification } & \multirow{2}{*}{$\begin{array}{c}\text { Chi-Square } \\
\left(X^{2}\right)\end{array}$} \\
\hline & Yes (\%) & No $(\%)$ & Yes (\%) & No $(\%)$ & \\
\hline $\begin{array}{l}\text { Land management } \\
\text { practices }\end{array}$ & 70.3 & 29.7 & 90.1 & 9.9 & $40.34^{* * *}$ \\
\hline Terracing & 67.9 & 32.1 & 81.6 & 18.4 & $55.82 * * *$ \\
\hline Manure use & 70.6 & 29.4 & 84.8 & 15.2 & $10.92^{* * *}$ \\
\hline Compost use & 58.0 & 42.0 & 78.1 & 21.9 & $4.28 * *$ \\
\hline
\end{tabular}


The certification has positive effects on increasing crop productivity. Table 8 gives evidence that the changed land management practices also have influenced the crop yields of the investigated farm households. For major crops, yields of the year 2005 (before certification) were compared with yields of the year 2018 (after certification). On average, wheat increased from 6.12 quintal to 10.42 quintal, teff from 5.52 quintal to 8.45 quintal, sorghum from 3.87 quintal to 7.02 quintal and barley from 3.42 quintal to 5.15 quintal.

Table 8. Comparison of major crop types produced in 2005 (before certification) and 2018 (after certification). One quintal equals $100 \mathrm{~kg}$.

\begin{tabular}{ccccc}
\hline \multirow{2}{*}{ Crop Type } & \multicolumn{2}{c}{$\begin{array}{c}\text { Crop Yield in 2005 (in Quintal) } \\
\text { (Before Certification) }\end{array}$} & \multicolumn{2}{c}{$\begin{array}{c}\text { Crop Yield in 2018 (in Quintal) } \\
\text { (After Certification) }\end{array}$} \\
\cline { 2 - 5 } & Mean & Standard Deviation & Mean & Standard Deviation \\
\hline Teff & 5.52 & 3.36 & 8.45 & 4.13 \\
Wheat & 6.12 & 3.43 & 10.42 & 5.92 \\
Sorghum & 3.87 & 2.55 & 7.02 & 4.02 \\
Barley & 3.42 & 2.29 & 5.15 & 2.52 \\
Bean & 2.18 & 1.05 & 3.43 & 1.24 \\
Potato & 5.57 & 5.42 & 7.79 & 5.25 \\
Milet & 4.16 & 2.37 & 5.08 & 3.44 \\
Niger & 2.81 & 1.32 & 3.13 & 1.26 \\
\hline
\end{tabular}

\subsection{Collinearity Check}

A contingency coefficient test was also performed to evaluate associations between dummy variables. As indicated in Appendix A, the results have shown that there are no problems with multi-collinearity between the variables and the contingency coefficient test result has been good and are included in the model for analysis.

\subsection{Factors Influencing Perceived Tenure Security}

The logit model was used to analyze the factors influencing the perceived security of tenure. Farming households were either expected to lose farmland with redistribution over the next five years or not. As an indicator the variable 'Fear of future land redistribution within the next five year' was used as a binary variable. The logit model was estimated using the iterative maximum likelihood estimation procedure. Table 9 shows the results of the model.

The results of the model confirmed that farming households expect fear of land redistribution within the next five years. This fear is influenced by the interaction of several factors. The Chi-square value shows that the parameters included in the model were significantly different from zero at $p<0.001$ probability level. The model's goodness was also valuated by the Hosmer and Lemeshow test [49]. Being greater than 0.05, the calculated value of the Hosmer and Lemeshow test confirmed the goodness of the model.

Another measure of goodness of fit was based on a scheme, which classified the predicted value of the dependent variable 'Fear of land redistribution over next five years' as 1 if $p(\mathrm{i}) \geq 0.5$ and as 0 otherwise. The model correctly classifies $94.8 \%$ of the overall cases.

Table 9 gives evidence about all signs, magnitudes and statistical significance of the estimated parameters. The age of the household head was found to be significant at $p<0.001(0.1 \%)$ probability level. Total farm size was significant at $p<0.01(1 \%)$ probability level and variables educational level, total size of household and affected by land redistribution in 1997 were found to be significant at $p<0.05(5 \%)$ probability level. 
Table 9. Factors affecting the fear of land redistribution within the next five years.

\begin{tabular}{cccccc}
\hline Explanatory Variables Name & B & S.E. & Wald & Sig. & Exp(B) \\
\hline Type of household & 0.012 & 0.670 & 0.000 & 0.986 & 1.012 \\
Sex of household head & -0.458 & 0.800 & 0.327 & 0.567 & 0.633 \\
Age of household head & 0.180 & 0.048 & 14.191 & $0.000^{* * *}$ & 0.835 \\
Educational Level & 2.274 & 0.968 & 5.517 & $0.019^{*}$ & 9.720 \\
Total size of household & -0.379 & 0.156 & 5.899 & $0.015^{*}$ & 1.460 \\
Total farm size & 1.670 & 0.502 & 11.060 & $0.001^{* *}$ & 0.188 \\
Affected by land redistribution & 2.001 & 0.927 & 4.661 & $0.031^{*}$ & 7.398 \\
Fear about take-over land by government & 1.978 & 1.534 & 1.662 & 0.197 & 7.227 \\
Total livestock & -0.176 & 0.135 & 1.721 & 0.190 & 0.838 \\
$\quad$ Constant & 14.393 & 3.106 & 21.466 & 0.000 & 1.781 \\
\hline Correct Predicted Percentage & \multicolumn{5}{c}{$94.8^{\text {a }}$} \\
Omnibus tests of model coefficients & \multicolumn{5}{c}{ Chi-square: $242.198 ;$ (Sig. 0.000) } \\
Number of cases
\end{tabular}

* Significant at $5 \%$ level. ** Significant at $1 \%$ level. ${ }^{* * *}$ Significant at $0.1 \%$ level. B (coefficients); S.E. (standard errors);

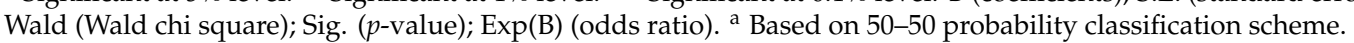

\subsection{Factors Influencing Terracing before and after Land Certification}

The logistic regression model has been used to analyze the factors that influence terracing. The logistic regression model has been estimated using the iterative maximum probability estimation method. The results of the model are shown in Table 10.

Table 10. Effect and influencing factors of land certification on terracing before and after certification.

\begin{tabular}{|c|c|c|c|c|c|c|}
\hline \multirow{2}{*}{ Independent Variables Name } & \multicolumn{3}{|c|}{ Before Land Certification } & \multicolumn{3}{|c|}{ After Land Certification } \\
\hline & B & Sig. & $\operatorname{Exp}(B)$ & B & Sig. & $\operatorname{Exp}(B)$ \\
\hline Total farm size & 0.650 & $0.009 * *$ & 1.916 & 1.297 & $0.002 * *$ & 3.658 \\
\hline Distance farm to homestead & -0.539 & $0.000 * * *$ & 0.583 & -0.517 & $0.004 * *$ & 0.597 \\
\hline Perception of degradation & 1.376 & $0.000 * * *$ & 3.959 & 2.402 & $0.000^{* * *}$ & 4.044 \\
\hline Access to credit & 0.751 & $0.015^{*}$ & 2.120 & 1.651 & $0.001^{* *}$ & 5.211 \\
\hline Training to Land Resource Management & 1.838 & $0.000 * * *$ & 6.284 & 2.251 & $0.000^{* * *}$ & 9.495 \\
\hline Fear about take-over land by government & -2.475 & $0.011 *$ & 3.923 & -0.856 & $0.000^{* * *}$ & 2.354 \\
\hline Total livestock & 0.156 & 0.018 * & 0.856 & 0.593 & $0.000^{* * *}$ & 1.809 \\
\hline Constant & -1.028 & 0.129 & 0.358 & -4.620 & 0.000 & 0.010 \\
\hline Correct Predicted Percentage & \multicolumn{3}{|c|}{$84.3^{\mathrm{a}}$} & \multicolumn{3}{|c|}{$92.1^{\mathrm{a}}$} \\
\hline Omnibus tests of model coefficients & \multicolumn{3}{|c|}{ Chi-square: $160.934^{* * *}$} & \multicolumn{3}{|c|}{ Chi-square: $191.300 * * *$} \\
\hline Number of cases & \multicolumn{3}{|c|}{343} & \multicolumn{3}{|c|}{343} \\
\hline
\end{tabular}

The model results confirmed that the interaction of several factors influenced the farming households on terracing before and after certification. Table 10 gives evidence about the variables assumed to explain the decision of farming households to construct terraces for both before and after certification. The perceptions of degradation and land resource management training were found to be significant at a $p<0.001(0.1 \%)$ probability level for both before and after certification. Similarly, for both before and after certification, total farm size was significant at $p<0.01(1 \%)$ probability level. Fear about take-over land by government and total livestock were significant at $p<0.001(0.1 \%)$ probability level only after certification. In addition, average distance of farm plot from homestead and access to credit were significant at $p<0.01(1 \%)$ probability level after certification, whereas access to credit, fear about take-over land by government and total livestock were significant at $p<0.05(5 \%)$ probability level before certification. One of the determinant average distance of farm plot from homestead significant at $p<0.001(0.1 \%)$ probability level before certification. The descriptive statistics also showed that terracing increased by more than $13 \%$ after land certification. All estimated parameters of the signs, magnitudes and statistical significance are documented in Table 10. 


\subsection{Factors Influencing Use of Manure before and after Land Certification}

The logit regression was used to analyze the factors that influence the use of manure by farming households before and after certification. Consequently, the variable manure use has been used as a binary variable. The logit model was estimated using the method of iterative maximum probability. Model results are displayed in Table 11.

Table 11. Effect and influencing factors of land certification on manure use before and after certification.

\begin{tabular}{|c|c|c|c|c|c|c|}
\hline \multirow{2}{*}{ Independent Variables Name } & \multicolumn{3}{|c|}{ Before Land Certification } & \multicolumn{3}{|c|}{ After Land Certification } \\
\hline & B & Sig. & $\operatorname{Exp}(B)$ & B & Sig. & $\operatorname{Exp}(B)$ \\
\hline Total farm size & 0.523 & $0.030 *$ & 1.687 & 0.697 & 0.091 & 2.007 \\
\hline Distance farm to homestead & -0.419 & $0.001 * *$ & 0.512 & -0.506 & $0.009 * *$ & 0.603 \\
\hline Perception of degradation & 0.767 & $0.016^{*}$ & 2.153 & 1.928 & $0.000^{* * *}$ & 6.873 \\
\hline Access to credit & 0.622 & $0.047 *$ & 1.862 & 2.314 & $0.000^{* * *}$ & 3.581 \\
\hline Training to Land Resource Management & 1.385 & $0.000 * * *$ & 3.995 & 1.999 & $0.000 * * *$ & 7.380 \\
\hline Fear about take-over land by government & -1.855 & $0.037^{*}$ & 2.103 & -0.685 & $0.001^{* *}$ & 1.984 \\
\hline Total livestock & 0.329 & $0.000 * * *$ & 0.639 & 0.388 & $0.000 * * *$ & 0.678 \\
\hline Constant & 0.393 & 0.519 & 1.481 & 0.393 & 0.519 & 1.481 \\
\hline Correct Predicted Percentage & \multicolumn{3}{|c|}{$86.3^{\mathrm{a}}$} & \multicolumn{3}{|c|}{$91.8^{\mathrm{a}}$} \\
\hline Omnibus tests of model coefficients & \multicolumn{3}{|c|}{ Chi-square: $153.309^{* * *}$} & \multicolumn{3}{|c|}{ Chi-square: $159.204^{* * *}$} \\
\hline Number of cases & \multicolumn{3}{|c|}{343} & \multicolumn{3}{|c|}{343} \\
\hline
\end{tabular}

${ }^{*}$ Significant at $5 \%$ level. ${ }^{* *}$ Significant at $1 \%$ level. ${ }^{* * *}$ Significant at $0.1 \%$ level. B (coefficients); S.E. (standard errors);

Wald (Wald chi square); Sig. ( $p$-value); $\operatorname{Exp(B)~(odds~ratio).~}{ }^{a}$ Based on 50-50 probability classification scheme.

The results of the model confirmed the a priori assumption that the use of manure by farming households before and after certification was affected by several factors. The Chi-square value shows that the parameters included in the model at the probability level $p<0.001$ for both before and after certification were significantly different from zero. Another indicator of the model's goodness is the Hosmer and Lemeshow test [49]. The value of the Hosmer and Lemeshow test applied is greater than 0.05 , indicating the goodness of the model both before and after certification.

An additional measure of goodness of fit was based on a scheme that classified the predicted value of the dependent variable manure use as 1 if $p(\mathrm{i}) \geq 0.5$ and 0 otherwise. The model correctly classifies $86.3 \%$ before certification and $91.8 \%$ after certification of the total cases.

The estimated parameter signs, magnitudes and statistical significance are shown in Table 11. Of the seven variables assumed to explain farming households manure use for both before and after certification, training to Land Resource Management and total livestock were found to be significant at $p<0.001(0.1 \%)$ probability level. Table 11 also give evidence that the average distance of farm plot from homestead was significant at $p<0.01(1 \%)$ probability level for both before and after certification. After certification, perception of degradation and access to credit were significant at $p<0.001(0.1 \%)$. Similarly, fear about take-over land by government was significant at $p<0.01(1 \%)$ after certification, whereas total farm size, perception of degradation, access to credit and fear about take-over land by government were significant at $p<0.05(5 \%)$ probability level before certification. Descriptive statistics also showed that the application of manure increased by about $14 \%$ after land certification (see Table 11).

\section{Discussion}

\subsection{Benefits of Land Certification}

Evidently, farming households were strongly convinced that land certification has brought distinctive benefits to users. These results were also supported by group discussions, which argued that the landholding certificate is being used as proof of their landholding rights and increased land tenure security. The results of this study are well aligned with the findings in literature. Studies 
reported that most households (81\%) developed a sense of ownership following land certification in Kilite Awela'elo woreda, Tigray Region [50]. Similarly, 100\% of farmers in Worja and $97.5 \%$ in Beressa agreed that they would inherit their land [51]. In addition, similar results in southern Ethiopia documented that land certification has contributed to increasing perceptions of tenure security among small-scale farmers [52]. Certification is a step forward to ensure tenure security and landholding right, because land tenure security refers to the degree of confidence held by people that they will not be arbitrarily deprived of the land rights enjoyed and/or of the economic benefits. It includes both objective elements (nature, content, clarity, duration and enforceability of the rights) and subjective elements (landholders' perception of the security of their rights) as explained by [53,54]. In the focus group discussion, it was reported that farm households are quite confident that the certificates will help them inherit their land to their children. However, very few participants revealed that the land certification will never provide tenure security just because the certificate is not a "Bible" or "Qur'an" and can be changed at any time if there is a change in government. Land certification has also increased land rental and sharecropping, which is also confirmed in several other studies [50,52,55]. Another benefit of registration is that certificates can be used as collateral evidence to a financial institution to obtain loans for the purchase of farm inputs. This is in line with the study of Deininger [8]. However, the focus group discussions gave evidence about the lack of awareness among farm households to use certificates as a means of obtaining farm input credits.

The revised Rural Land Administration and Use Policy (RLAUP) of the Amhara National Regional State (ANRS) Proclamation No. 133/2006 referred to in Article 24 (2) provides that the land is held jointly by the husband and the wife, and the land holding certificate shall be drawn up in the name of both spouses [56]. Thus, the joint title implies the implementation of the land declaration, which led to an increased number of households headed also by female persons as it can be seen in Table 3.

\subsection{Perception and Confidence about Land Tenure Security after Land Certification}

The land redistribution in 1997 had affected $43.4 \%$ of the investigated farming households (see Table 5). This finding is a updated trend of the results of Deininger et al. [55], who found in 2003 that $9 \%$ of the farmers in Ethiopia, $18 \%$ in Tigray and 21\% in Amhara region were affected by land redistribution between 1991 and 1998. Another study similarly confirmed that 43\% titled and 35\% untitled of the sampled farmers in Amhara National Regional State (ANRS) were affected by land redistribution in 1997 [57].

More than $80 \%$ of the investigated farming households are confident that there will be no redistribution of land over the next five years. Some of them are expecting redistribution of land caused by the change in family size and increasing trends of landless youths in the rural area that could pressure the government to launch a new land redistribution. The results of this study are in line with findings in the Tigray Region (Ethiopia) that despite the regions' declaration of stopping further land redistribution with exceptions of settlement and irrigation areas, $30 \%$ of households are suspecting future land redistributions [58]. Another study has shown that only $27 \%$ of farmers in Ethiopia are confident that there will not be land redistribution in the future and $9 \%$ expect that land redistribution will happen within the next five years [55]. Given the objective of land certification, few numbers of farm households fearing redistribution of land over the next five years and those farm households need to be properly addressed by the government if land investment is to be improved.

All these studies outline a declining trend in the fear of land redistribution, which could arise from land security because of land certification. In focus group discussion, some discussants reported that redistribution is expected on land holdings held by public servants and by old-aged farmers with large sized farming land and communal grazing land. Hence, the current pressure and efforts to push and own communal lands could be rooted in such perceptions. In the district, communal grazing land has been redistributed to landless households, e.g., to women, the disabled, the youth and the poorest of poor. In the study area, governmental administrators regulate communal grazing land. 
In the district close to the city of Debre Markos, some farming households fear the government's expropriation of land at any time when the land is considered necessary for development purposes. In accordance with in the Amhara Region Rural Land Administration and Use Policy 133/2006 [56], the government can expropriate land whenever it is deemed necessary for development purposes. The focus group discussants argued such fears in the rapid expansion of the city, which requires rural land for housing, infrastructure expansions, investments and industrialization purposes. The discussants also criticized the amount of compensations paid in case of expropriation from their land, as compensation did not consider variations in land quality and productivity such as fertility status of the land and is not flexible enough to capture changes in market prices of products and inflations. Since trees are better considered in calculating the compensation costs, farmers around city peripheries opted to plant Eucalyptus, which might cause environmental problems in the future. The results of the study were the same to that of Deininger et al. [14], who documented that 19\% of farmers expected a decrease of their farm plot size due to potential expropriation. In the focus group discussion, the majority of participants was more confident to receive compensation in cases of expropriation.

\subsection{Effect of Land Certification on Land-Related Conflicts}

A large number of farm households $(71.7 \%$ see Table 6$)$ indicated that the number of land-related disputes after certification was lower than before. This is in line with various studies documenting the prevention of land-related conflicts as positive effect of land registration and certification [50-52,59]. During group discussions, key informants and experts from district courts confirmed that the certification of land has specifically reduced boundary disputes and therefore conflicts. The discussants said that farm households are quite confident that no one can claim their land and that, in the case of a conflict, certificates can be used as a proof of their holdings. Their land certificates reduce the boundary conflict with their neighbors and there is no disagreement on this issue, particularly on the redistribution of land, when each plot is demarcated and mapped. However, the discussants also mentioned that in cases of differences between the land holding book certificates and what is found on the ground, the resolve of disputes is difficult. Therefore, they recommended maintaining and correcting what already had been done. Cases of disagreement should be solved with the help of the elder members in the kebele.

\subsection{Effect of Land Certification on Land Management Practices and Crop Yield}

Our study found that land certification has a positive effect on land management (see Table 7). This finding is similar with studies reporting that households were involved in different types of long-term land investment practices after land certification and that agricultural productivity increased as compared to before certification [50]. Similarly, studies have shown that land certification increases investment in land and land management [39,51]. A key motivation for issuing certificates is to increase land-related investments for sustainable land management [14]. In addition, results gained from the focus group discussion showed that land certification addressed gender inequality problems, which have prevailed for many years. Therefore, certification significantly increased women holding rights and improved decision-making in land related issues such as land management practices. Studies confirmed that women's willingness to work in the field and applying proper land management practices has been increased after the certification process [51]. Improving the protection of women's land rights after certification (based on the revised Amhara Rural Land Administration and Use (ARLAU) Proclamation No. 133/2006) may lead female farmers to take care of their farmland. This finding was supported by studies that land certification contributed to increased women's tenure security, promoted gender equality and increased participation in land management practices [39,51,52]. Similarly, studies indicated that the certificates promote gender equality and the willingness of females to work in the field [52]. Only a few participants in the group discussion have revealed that land management practices were not based on certificates, but other parameters such as using artificial fertilizers Urea and Dap. They pointed out that land is a basic source of livelihood and that it is society's 
duty to protect the land from mismanagement, such as the protection of soil erosion, in order to ensure farmers can maintain production, whether or not they have certificates. Furthermore, the participants in the focus group discussion found that even if land certification improves land management practices, some farm households cultivate steep slopes, which means a lack of proper land use systems.

Improvement of land management practices after certification has been accompanied by positive effects on crop yields [57]. In addition, according to the report in the focus group discussion, land certification has a decisive effect on crop yields. For instance, farmers have reduced fear of short-term land redistributions and thus they are encouraged to invest in land management practices, to spend more time in their farmland and to increase the use of improved seeds and fertilizers with the aim of improving yields and farmland productivity (see Table 8).

\subsection{Factors Influencing Perceived Tenure Security}

The age of the household head is positively and significantly associated with the fear of a future redistribution of land. The likelihood of perceived tenure security decreases with increasing age of the head of the household. According to Table 9, by increasing the age of households' head by one-year and keeping other explanatory variables constant, the odds ratio in favor of fear of a future redistribution of land increases by a factor of 0.835 . In focus group discussions and key person interviews, this finding was justified that memories on previous land reforms are more evident by elder farmers, and therefore, they fear a redistribution of land in the future.

Total household size negatively affected perceived tenure security. Table 9 shows that if households are decreased by one member, the fear of redistribution of land increases by a factor of 1.46 . Thus, the head of the family is likely to have a relatively small number of dependents and a large farmland size. Land that is in excess will be taken away by the government body at any time, and that is why they are increasing their fear of redistribution of land in the future.

The educational level of the household head has a positive and significant impact on the fear of redistribution of land. Household heads who are literate are more likely (9.720 times higher) to fear a redistribution of land than illiterate household heads (Table 9). The educational level of households increases the possibility of finding alternative employment opportunities and participating in off- farm activities; because of the above, the government is likely to take over the land at any time, and this results in the growing fear of losing farmland. This result of a household survey is in line with the revised Amhara Rural Land Administration and Use (ARLAU) Proclamation No. 133/2006, enacted in Article 12 (1a), which provides that any holder who has the right to use the land may be deprived of that right if he engages in non-farming activities and earns his livelihood there [56]. Consequently, households fear that, as education levels increase, the likelihood of non-agricultural activity will increase, which may not be sufficient to meet the primary needs of individuals but will lead to the loss of farmland. On the contrary, this finding is not consistent with the results of the study reported by Pender et al. [26].

The households affected by the redistribution of land in 1997 have a significant and positive relationship with the fear of redistribution of land. According to Table 9, the increase in the number of households affected by the redistribution of land by one category in 1997, the fear of redistribution of land would increase by a factor of 7.398. However, total livestock holdings do not have a significant relationship, but there is a negative direction in the fear of redistribution of land. An increase of one unit in total household livestock holdings decreases the fear of redistribution of land by a factor of 0.838. This can be explained-as mentioned in focus group discussions-that farmers with more livestock generate additional income by selling livestock.

The model output about the total land holding size of households showed a positive and significant association with the fear of future redistribution of land. The analysis gave evidence that when total land size is increased by one hectare, the probability of the households with fear of redistribution of land in the future increases by a factor of 0.188 (Table 9). Households with large land holdings show an increased fear about the redistribution of their land and a loss of their farmland. This result of the 
household survey is consistent with the outcome of the focus group discussion. The participants said that an increasing number of landless young people are threatening their farms, as food insecurity and crime/robbery are increasing. As a result, land could be redistributed from old people with large farm sizes to landless younger people. The results of the current study are supported by findings that farm households with relatively larger farms feel more insecure than those with relatively less land and the tenure security of farm households in Ethiopia is inversely related to the size of the farm [28].

Table 5 indicates that the fear of land redistribution in general is high and smoothly higher within the next five years than beyond. Some participants in the focus group discussion indicated that there has been frequent land redistribution in past days. They do not know what is happening in the future as this depends on the government and its policy. The fear comes even in the land policy, which states that land redistribution could be possible, if the land will be needed for irrigation projects. Another fear is that the government could be substituted and afterwards the legislation would not be executed properly.

\subsection{Factors Affecting Land Investment (Terracing and Manure Use)}

Total land holding size of a household in generals has smooth but significant impacts on terrace construction (Table 10). This can be explained by the fact that larger farms are associated with greater wealth and increased availability of capital, which increases the likelihood of investment in land. Rogers [60] and Teshome et al. [61] also referred to these farmers as innovators who accepted new technologies earlier than others. In addition, studies have shown that the size of the land has a positive effect on the adoption of land management practices. This can be attributed to the fact that conservation structures occupy part of the productive land and farmers with larger farm size can afford retaining structures compared to those with relatively smaller farm size [62,63]. Similar studies have shown that farmers who maintain larger farms are more likely to apply land management practices than those whose farms are relatively small [64,65]. In addition, one study carried out in the Ethiopian Beressa watershed confirmed that farmers with a small farm size have fewer soil and stone terraces [66].

On the contrary, studies have explained that the majority of farmers who cultivate more land are older farmers, and often, these farmers lack the workforce [67]. Thus, to solve labor force problems, old-age farmers hire workers who have been used to maintain conservation structures [67]. Larger farms may find it easier to produce sufficient surpluses to build up investment by using mechanization than smaller farms [68]. Farmers with larger parcels may allocate more land to soil conservation than those with smaller farms [69]. This can be justified by a better perception and more experiences about soil erosion by older farmers. Therefore, older farmers are making more effort to apply land management practices compared to younger ones because of their experiences gained. The reason for this, as identified in the focus group discussions, is that elder people have increased experience, knowledge, skill and attitudes to cultivate land and have relatively large farms. Similar studies indicate the adoption of land management practices by older farmers [64,70]. Previous ones reported that younger farmers do not devote more effort to land management practices (cut-off drain) compared to older ones $[63,65,71]$.

In addition, the total land holding size of a household has a positive and significant impact on the use of manure before certification. Thus, the increase in total land holdings of a household by one category would increase the application of manure by a factor of 1.687 before certification (Table 11). The majority of the participants in the focus group discussion said that as the total land holding size increases, farmers need a large number of livestock to apply manure to all their plots. However, in case the farm household does not have a large livestock, it is difficult to use manure for such a large plot of land.

The distance of a farm plot from homestead has some negative effects on the construction of terraces. Farming households with farmland near residential areas have a higher probability of building terraces than farm households with farmlands relatively far from homestead (Table 10). This can be attributed to the fact that farming households give more attention to nearby farm plots than to distant 
plots. Similarly, the same is true for manure use (Table 11). Distance also matters because manure is very bulky and therefore difficult to transport. Studies report that less time and energy are needed to manage close farmland with the result that longer walking distance between farmland and residential area reduce the adoption of land cultivation $[62,72]$.

The perception of households about land degradation is a driving force to build terraces. If household heads had the perception that land is degraded, the likelihood of terrace construction is higher by a factor of 3.959 before and 4.044 after certification compared to those households that did not have this feeling (Table 10). Similar results can be seen on the use of manure. In this case, the factors are 2.153 before certification and 6.873 after certification (Table 11). The higher factors after certification give evidence that the land certification process also improved land cultivation practices. The positive impact of land certification on land cultivation practices was also confirmed in focus group discussions and by key informants.

It was interesting that the access to credits was significant and positively related to improving the land management practices (terracing and manure use). Farm households that have access to credit were applying terracing 2.120 times more before certification and 5.211 times more after certification (Table 10). In the same way, a unit increase in credit access increased the use of manure by a factor of 1.862 before and 3.581 after land certification (Table 11). Farm households with better access to loans were expected to invest more in land management practices. Studies have reported that credit services for agricultural inputs could increase the adoption of conservation measures by farmers [71]. On the other hand, another study reported that access to credit could reduce conservation investment by enabling farmers to mask the short-term effects of land degradation [73]. In this sense, the results of the current study are plausible.

Farm households that had access to training in land resource management applied terracing 6.284 times before certification and 9.495 times after certification (Table 10). Land resource management training also has a positive and significant impact on the application of manure before and after land certification. The factors are similar. An additional training unit by one day in land resource management increased the use of manure by a factor of 3.995 before and 7.380 after land certification (Table 11). This significant increase is the result of the provision of adequate information and training on land management practices. The participants in the focus group discussion also confirmed that farm households that get a higher number of trainings were motivated in the construction of terraces for their farmlands. The application of organic manure is also due to the training that farm households received in composting. Participants agreed to be more influenced by the extension services provided to them than by development workers to make such land investments. Former studies have shown that training of farmers could increase the probability of adoption, utilization and implementation of land management practices [72]. Access to training will increase farmers' attitudes and skills in land management and reflect a better understanding of the benefits and constraints of soil conservation. Training also improves the ability to acquire and apply specific knowledge on the use of land management activities. Previous findings showed that training increased the adoption of land management practices $[62,65,72,74]$. Various evidence exists regarding the relationship between the training of farmers and the application of sustainable land management practices by farmers [75]. The results of the current study also highlighted that the influence of training offered was increased after the land certification process.

The terrace construction decision was negatively and significantly related to the fear that the government would take over land at any time before and after certification. If household heads at any time feared the government's takeover of land, the likelihood of terrace construction is-compared to those households who did not fear this-lower by a factor of 3.923 and 2.354, respectively, before and after certification (Table 10). Similarly, the fear of the government taking over land at any time was negatively and significantly related to the decision to apply manure before and after certification. In this case, the factors are 2.103 before certification and 1.984 after certification (Table 11). Therefore, we can deduce that the fear of losing farmland as a result of redistribution by the government at any 
time was high before certification. The focus group discussion also confirmed that, before certification, there is a fear of redistribution of land and government taking over land and risk in the holding right, but after certification, the risk of redistribution of land is expected to be reduced. If the government needs the land for development purposes, the government pays compensation for the land lost.

The decision to build a terrace was related positively and significantly to the total number of livestock holdings before and after certification. A one-unit increase in livestock would increase the construction of the terrace by a factor of 0.856 before certification and 1.809 after certification (Table 10). The probable reason is that there is a low family size, a shortage of work force and a large number of livestock. There is a possibility of selling livestock and converting to human work force. It is possible, then, to construct a terracing of the human work force gained out of the family members. The focus group discussion also confirmed that when farm households have a shortage of labor, the sale of livestock used to purchase additional human labor for the construction of terraces. Former studies also confirmed the results of this study $[62,63,71,74]$. Similarly, the total number of livestock holding had a significant and positive impact on the decision to use manure before and after certification (Table 11). This is justified because the source of manure is livestock, and therefore, total number of livestock holding matters. Another explanation for the increased use of manure for agricultural production mentioned in the focus group discussions was a rise of prices for inorganic fertilizer. The size of the livestock is expected to influence the use of manure, as more livestock can produce more manure [76]. Farmers with large numbers of livestock have more dung to improve soil fertility and in general, more capital to invest in land management practices. The number of livestock is also an indicator of wealth that may ease capital constraints. Household wealth, as indicated by the total number of livestock units, may be a sign of power and may reduce tenure insecurity [28]. In addition, livestock is an important source of farm income and enables farmers to purchase agricultural inputs and invest in land management practices. It also serves as nonhuman labor for the construction of soil conservation structures [66,76]. Studies also showed that the number of livestock is an indicator of economic security, which had a positive influence on the performance of land management [63,71].

\section{Summary, Conclusions and Recommendations}

One of the key issues in the Ethiopian land Administration system is the registration and certification of landholdings in order to enhance the security of land tenure. To this end, the land registration and certification program has been launched in Ethiopia since 1998 and in Amhara region in 2002 with the aim of registering all land holdings and granting holding certificates in order to increase the security of the farmer's land rights. Theoretically, land certification is a catalyst for economic growth by providing incentives to boost agricultural investment and productivity. Secure property rights are crucial for economic development. Land certification programs are one way to address the issue of weak property rights.

The current study gives evidence that in Gozamin district the land certification process increased land tenure security for farm households. It also confirmed additional benefits of land certification, such as the reduction of land boundary conflicts and the enabling of land rent and sharecropping. Registration and certification of land also improved farm decisions for households to invest in land.

With respect to the impact of land certification on land investment and land resource management, the participation of households in land management practices such as terracing and use of manure has also shown an improvement after land certification.

The logit model identified specific variables with significant impact on terrace construction and manure use. These findings could be used to trigger the sustainable use and construction of terraces as an investment in land for farming households. The increased crop productivity is a quantitative proof of the success of the land certification process. Based on the investigations carried out in the study and in the findings achieved, the authors recommend activities highlighted in the following paragraphs.

In general, land certification enhanced farm households' perceptions and confidence in land tenure security, but still some farm households fear future redistribution of their land. The governmental 
bodies can mitigate this fear by revising the land policy. For example, the confusion stems from the policy itself. Policy documents state that land redistribution could be possible if land is required for irrigation projects. Policy has to define the reasons for redistribution clearly to increase farmers' feeling about security of land use rights. Moreover, continuous awareness creation of land users might be important to avoid unfounded fears.

Authorities should also provide information about the importance and possibilities of land certificates, as the current study identified a lack of awareness among farm households about the use of certificates as using their land as collateral to obtain farm input credits.

Although land certification improves land management practices, some farm households are cultivating steep slopes, which implies that no proper land use planning is available. Thus, the development and implementation of land use plans is urgently required, which prescribes the purpose for which a specific plot of land has to be used.

The study gave evidence that distances between farm plots and homestead have a negative impact on land management practices. Land consolidation would be a proper tool to improve this situation. The governments have to provide the legal frame and means to enable land consolidation processes.

Author Contributions: Conceptualization, A.A.G. and R.M.; methodology, A.A.G. and W.S.; validation, A.A.G. and R.M.; formal analysis, A.A.G.; investigation, A.A.G. and W.S.; resources, A.A.G., W.S. and R.M.; data curation, A.A.G.; writing-original draft preparation, A.A.G.; writing-review and editing, R.M., C.A. and W.S.; visualization, A.A.G. and R.M.; supervision, R.M. and C.A.; project administration, R.M. and S.K.A.; funding acquisition, R.M. and S.K.A. All authors have read and agreed to the published version of the manuscript.

Funding: This research was enabled by a scholarship funded by the Austrian Development Cooperation within the Austrian Partnership Program in Higher Education and Research for Development (APPEAR). Project no. 113 "Implementation of Academic Land Administration Education in Ethiopia for Supporting Sustainable Development" (EduLAND2).

Acknowledgments: The authors thank the farming households, land use and land administration experts in the study area for their collaboration during survey interviews.

Conflicts of Interest: The authors declare no conflict of interest. The funders had no role in the design of the study; in the collection, analyses or interpretation of data; in the writing of the manuscript, or in the decision to publish the results.

\section{Appendix A}

Before estimating the logit model, the severity of the multi-collinearity (linear relationship) between explanatory variables was checked by computing the Variance Inflation Factor (VIF). A VIF less than 10 indicates the absence of multi-collinearity.

Table A1. Multi-collinearity test for perceived tenure security (variables see Table 2).

\begin{tabular}{cc}
\hline Continuous Independent Variables & VIF \\
\hline Age of household head & 1.237 \\
Total size of household & 1.148 \\
Total farm size & 1.159 \\
Total number of livestock & 1.266 \\
\hline VIF is Variance inflation Factor; Source: Survey, 2018.
\end{tabular}

Table A2. Multi-collinearity test for land-related investment (Terracing and manure use).

\begin{tabular}{ccc}
\hline \multirow{2}{*}{ Continuous Independent Variables } & \multicolumn{2}{c}{ VIF } \\
\cline { 2 - 3 } & Before Certification & After Certification \\
\hline Total farm size & 1.194 & 1.172 \\
Average distance between farm and & 1.271 & 1.261 \\
$\quad$ homestead & 1.149 & 1.139 \\
Total livestock &
\end{tabular}

VIF is Variance inflation Factor; Source: Survey, 2018. 
Table A3. Contingency coefficients for dummy independent variables for perceived tenure security.

\begin{tabular}{cccccc}
\hline & Joint & Female & $\begin{array}{c}\text { Educational } \\
\text { Level }\end{array}$ & $\begin{array}{c}\text { Affected by Land } \\
\text { Redistribution }\end{array}$ & $\begin{array}{c}\text { Fears of the } \\
\text { Government }\end{array}$ \\
\hline Joint & 1 & & & & \\
Female & 0.431 & 1 & & & \\
Educational Level & 0.062 & 0.021 & 1 & 1 & 1 \\
Affected by land redistribution & 0.028 & 0.042 & 0.031 & 0.019 & 1 \\
Fears of the Government & 0.063 & 0.075 & 0.015 & & \\
\hline
\end{tabular}

Table A4. Contingency coefficients for dummy independent variables for land-related investment (Terracing and manure use).

\begin{tabular}{ccccc}
\hline & $\begin{array}{c}\text { Perception of } \\
\text { Degradation }\end{array}$ & Access to Credit & Training to LRM & $\begin{array}{c}\text { Fears of the } \\
\text { Government }\end{array}$ \\
\hline Perception of degradation & 1 & 1 & & \\
Access to credit & 0.096 & 0.029 & 1 & 1 \\
Training to LRM & 0.052 & 0.017 & 0.023 & \\
Fears of the Government & 0.041 & & & 1 \\
\hline
\end{tabular}

\section{References}

1. Cotula, L.; Toulmin, C.; Hesse, C. Land Tenure and Administration in Africa: Lessons of Experience and Emerging Issues; International Institue for Enviroment and Development: London, UK, 2004; p. 50.

2. Toulmin, C. Securing land and property rights in sub-Saharan Africa: The role of local institutions. Land Use Policy 2009, 26, 10-19. [CrossRef]

3. Persha, L.; Fischer, H.; Chhatre, A.; Agrawal, A.; Benson, C. Biodiversity conservation and livelihoods in human-dominated landscapes: Forest commons in South Asia. Biol. Conserv. 2010, 143, 2918-2925. [CrossRef]

4. Porter-Bolland, L.; Ellis, E.A.; Guariguata, M.R.; Ruiz-Mallén, I.; Negrete-Yankelevich, S.; Reyes-García, V. Community managed forests and forest protected areas: An assessment of their conservation effectiveness across the tropics. For. Ecol. Manag. 2011, 268, 6-17. [CrossRef]

5. Atwood, D.A. Land registration in Africa: The impact on agricultural production. World Dev. 1990, 18, 659-671. [CrossRef]

6. Rahman, A.; Westley, J. The challenge of ending rural poverty. Dev. Policy Rev. 2001, 19, 553-562. [CrossRef]

7. Bonfiglioli, A.M. Empowering the Poor: Local Governance for Poverty Reduction; United Nations Capital Development Fund: New York, NY, USA, 2003.

8. Deininger, K. Land Policies for Growth and Poverty Reduction; World Bank and Oxford University Press: Washington, DC, USA, 2003.

9. Holden, S.T.; Deininger, K.; Ghebru, H. Tenure insecurity, gender, low-cost land certification and land rental market participation in Ethiopia. J. Dev. Stud. 2011, 47,31-47. [CrossRef]

10. Besley, T. Property Rights and Investment Incentives: Theory and Evidence from Ghana. J. Polit. Econ. 1995, 103, 903-937. [CrossRef]

11. Sjaastad, E.; Bromley, D.W. Indigenous land rights in sub-saharan africa: Appropriation, security and investment demand. World Dev. 1997, 25, 549-562. [CrossRef]

12. Gebremedhin, B.; Swinton, S.M. Investment in soil conservation in Northern Ethiopia: The role of Land Tenure Security and Public Programs. Agric. Econ. 2003, 29, 69-84. [CrossRef]

13. Holden, S.T.; Deininger, K.; Ghebru, H. Impacts of low-cost land certification on investment and productivity. Am. J. Agric. Econ. 2009, 91, 359-373. [CrossRef]

14. Deininger, K.; Ali, D.A.; Alemu, T. Impacts of land certification on tenure security, investment, and land market participation: Evidence from Ethiopia. Land Econ. 2011, 87, 312-334. [CrossRef]

15. Place, F. Land Tenure and Agricultural Productivity in Africa: A Comparative Analysis of the Economics Literature and Recent Policy Strategies and Reforms. World Dev. 2009, 37, 1326-1336. [CrossRef]

16. Palm, L. Quick and Cheap Mass Land Registration and Computerisation in Ethiopia; FIG Congress: Sydney, Australia, 2010; pp. 1-14. 
17. Deininger, K.; Jin, S.; Adenew, B.; Gebre-selassie, S.; Nega, B. Tenure Security and Land-Related Investment: Evidence from Ethiopia. World Dev. 2003, 50, 1-28.

18. Gavian, S.; Fafchamps, M. Land Tenure and Allocative Efficiency in Niger. Am. J. Agric. Econ. 1996, 78, 460-471. [CrossRef]

19. Hayes, J.; Roth, M.; Zepeda, L. Tenure Security, Investment and Productivity in Gambian Agriculture: A Generalized Probit Analysis. Am. J. Agric. Econ. 1997, 79, 369-382. [CrossRef]

20. Deininger, K.; Castagnini, R. Incidence and impact of land conflict in Uganda. J. Econ. Behav. Organ. 2006, 60, 321-345. [CrossRef]

21. Otsuka, K.; Place, F. Land Tenure and Natural Resource Management: A Comparative Study of Agrarian Communities in Asia and Africa; International Food Policy Research Institute: Baltimore, MA, USA, 2001.

22. Anley, Y.; Bogale, A.; Gabriel, A.H. Adoption Decision and Use Intensity of Soil and Water Conservation Measures by Smallholder Subsistence Farmers in Dedo District, Western Ethiopia. L Degrad. Dev. 2007, 18, 289-302. [CrossRef]

23. Holden, S.T.; Otsuka, K.; Deininger, K. Land Tenure Reform in Asia and Africa: Assessing Impacts on Poverty and Natural Resource Management, 1st ed.; Palgrave Macmillan: London, UK, 2013; pp. 1-430.

24. Deininger, K.; Jin, S. Tenure security and land-related investment: Evidence from Ethiopia. Eur. Econ. Rev. 2006, 50, 1245-1277. [CrossRef]

25. Deininger, K.; Ali, D.A. Do overlapping land rights reduce agricultural investment? evidence from Uganda. Am. J. Agric. Econ. 2008, 90, 869-882. [CrossRef]

26. Pender, J.; Place, F.; Ehui, S. Strategies for Sustainable Land Management in the East African Highlands; International Food Policy Research Institute (IFPRI): Washington, DC, USA, 2006; pp. 1-483.

27. Dalrymple, K. Expanding Rural Land Tenures to Alleviate Poverty. Ph.D. Thesis, The University of Melbourne, Melbourne, Australia, August 2005.

28. Holden, S.; Yohannes, H. Land redistribution, tenure insecurity, and intensity of production: A study of farm households in Southern Ethiopia. Land Econ. 2002, 78, 573-590. [CrossRef]

29. Zikhali, P. Fast Track Land Reform Programme, Tenure Security and Investments in soil conservation: Micro-evidence from Mazowe District in Zimbabwe. Nat. Resour. Forum 2010, 34, 124-139. [CrossRef]

30. Migot-adholla, S.; Hazell, P.; Blarel, B.; Place, F. Indigenous Land Rights Systems in Sub-Saharan Africa: A Constraint on Productivity? World Bank Econ. Rev. 1991, 5, 155-175. [CrossRef]

31. Feder, G.; Nishio, A. The benefits of land registration and titling: Economic and social perspectives. Land Use Policy 1999, 15, 25-43. [CrossRef]

32. Rahmato, D. Searching for Tenure Security? The Land System and New Policy Initiatives in Ethiopia; Forum for Social Studies: Addis Ababa, Ethiopia, 2004.

33. Federal Democratic Republic of Ethiopia. Federal Rural Land Administration and Land Use Proclamation; Federal Negarit Gazeta: Addis Ababa, Ethiopia, 2005.

34. Place, F.; Roth, M.; Hazell, P. Land Tenure Security and Agricultural Performance in Africa: Overview of Research Methodology. In Searching For Land Tenure Security in Africa; Bruce, J.W., Migot-Adholla, S.E., Eds.; The World Bank: Washington, DC, USA, 1994; pp. 15-39.

35. Teklu, T. Rural Lands and Evolving Tenure Arrangements in Ethiopia: Issues, Evidence and Policies; Forum for Social Studies: Addis Ababa, Ethiopia, 2003.

36. Deininger, K.; Chamorro, J.S. Investment and equity effects of land regularisation: The case of Nicaragua. Agric. Econ. 2004, 30, 101-116. [CrossRef]

37. Crewett, W.; Korf, B. Ethiopia: Reforming land tenure. Rev. Afr. Polit. Econ. 2008, 35, 203-220. [CrossRef]

38. Benin, S.; Pender, J. Impacts of land redistribution on land management and productivity in the Ethiopian highlands. L. Degrad. Dev. 2001, 12, 555-568. [CrossRef]

39. Deininger, K.; Ali, D.A.; Holden, S.; Zevenbergen, J. Rural Land Certification in Ethiopia: Process, Initial Impact, and Implications for Other African Countries. World Dev. 2008, 36, 1786-1812. [CrossRef]

40. Bezu, S.; Holden, S. Demand for second-stage land certification in Ethiopia: Evidence from household panel data. Land Use Policy 2014, 41, 193-205. [CrossRef]

41. Melesse, M.B.; Bulte, E. Does land registration and certification boost farm productivity? Evidence from Ethiopia. Agric. Econ. 2015, 46, 757-768. [CrossRef] 
42. Council of the Amhara National Regional State in the Federal Democratic Republic of Ethiopia. The Revised Rural Land Administration and Use Determination Proclamation of the Amhara National Regional State; Regional Zikre Hig Gazeta: Addis Ababa, Ethiopia, 2017.

43. Gedefaw, A.A.; Atzberger, C.; Seher, W.; Mansberger, R. Farmers willingness to participate in voluntary land consolidation in Gozamin District, Ethiopia. Land 2019, 8, 148. [CrossRef]

44. Gedefaw, A.A.; Atzberger, C.; Bauer, T.; Agegnehu, S.K.; Mansberger, R. Analysis of land cover change detection in Gozamin district, Ethiopia: From remote sensing and DPSIR perspectives. Sustainability 2020, 12, 4534. [CrossRef]

45. Cochran, W.G. Sampling Techniques, 3rd ed.; John Wiley and Sons: New York, NY, USA, 1977; Volume 3, pp. 89-97.

46. Feige, S.; Marr, M.A. Sampling Manual: A Guide to Sampling under the CDM with Special Focus to PoAs, 1st ed.; GmbH: Hamburg, Germany, 2012; pp. 1-97.

47. Gujarati, D.N. Basic Econometrics, 4th ed.; McGraw-Hill, Inc.: New York, NY, USA, 2003; pp. $15-297$.

48. Gelila, S. Farmers to Access Credit Using Land as Collateral; Fortune: New York, NY, USA, 2020.

49. Sarkar, S.K.; Midi, H.; Rana, S. Model selection in logistic regression and performance of its predictive ability. J. Appl. Sci. Res. 2010, 6, 5813-5822.

50. Menan, D.; Hagos, F. Implications of Land titling on Tenure Security and Long-term Land Investment: Case of Kilte Awela'elo Woreda, Tigray, Ethiopia. In Proceedings of the Collaborative National Workshop on Sustainable Land Management Research and Institutionalization of Future Collaborative Research, Mekelle, Ethiopia, 8-9 August 2008; pp. 259-280.

51. Giri, S. The Effect of Rural Land Registration and Certification Programme on Farmers' Investments in Soil Conservation and Land Management in the Central Rift Valley of Ethiopia. Ph.D. Thesis, Wageningen University, Wageningen, The Netherlands, 26 August 2010.

52. Stein, H.; Tefera, T. Land Registration in Ethiopia: Early Impacts on Women; United Nations Human Settlements Programme: Nairobi, Kenya, 2008.

53. Cotula, L.; Toulmin, C.; Quan, J. Better Land Access for the Rural Poor: Lessons from Experience and Challenges Ahead; Food and Agriculture Organization of the United Nations: London, UK, 2006.

54. Kanji, N.; Cotula, L.; Hilhorst, T.; Toulmin, C.; Witten, W. Can Land Registration Serve Poor and Marginalised Groups? International Institute for Environment and Development (IIED): Nottingham, UK, 2005.

55. Deininger, K.; Jin, S.; Adenew, B.; Gebre-Selassie, S.; Demeke, M. Market and Nonmarket Transfers of Land in Ethiopia: Implications for Efficiency, Equity, and Nonfarm Development; The World Bank Development Research Group: Washington, DC, USA, 2003.

56. Amhara National Regional State (ANRS). The Amhara National Regional State Rural Land Administration and Use System Implementation, Council of Regional Government Regulation; Regional Zikre Hig Gazeta: Bahir Dar, Ethiopia, 2006.

57. Tsegaye, A.; Adgo, E.; Selassie, G.Y. Impact of Land Certification on Sustainable Land Resource Management in Dryland Areas of Eastern Amhara Region, Ethiopia. J. Agric. Sci. 2012, 4, 261-268. [CrossRef]

58. Hagos, F. Land Registration and Land Investment: The case of Tigray Region, Northern Ethiopia. Ethiop. J. Econ. 2012, 21, 19-47.

59. Alemu, G. The Challenges of Land Tenure Reform to Structural Transformation of the Economy: Lessons from Country Experiences. In Proceedings of the 16th International Conference of Ethiopian Studies; Ege, S., Aspen, H., Teferra, B., Bekele, S., Eds.; NTNU-trykk: Trondheim, Norway, 2009; Volume 1-4.

60. Rogers, E.M. Diffusion of Innovations, 5th ed.; The Free Press: New York, NY, USA, 2003.

61. Teshome, A.; Rolker, D.; de Graaff, J. Financial viability of soil and water conservation technologies in northwestern Ethiopian highlands. Appl. Geogr. 2013, 37, 139-149. [CrossRef]

62. Kerse, B.L. Factors affecting adoption of soil and water conservation practices in the case of Damota watershed, Wolaita Zone, Southern Ethiopia. Int. J. Agric. Sci. Res. 2018, 7, 1-9.

63. Kebede, B.A.; Black, T.G.; Mideksa, D.F.; Nega, M.B. Soil and water conservation practices: Economic and environmental effects in Ethiopia. Glob. J. Agric. Econ. Econom. 2016, 4, 169-177.

64. Amsalu, A.; de Graaff, J. Determinants of adoption and continued use of stone terraces for soil and water conservation in an Ethiopian highland watershed. Ecol. Econ. 2007, 61, 294-302. [CrossRef]

65. Wolka, K.; Negash, M. Farmers' Adoption of Soil and Water Conservation Technology: A Case Study of The Bokole and Toni Sub-Watersheds, Southern Ethiopia. J. Sci. Dev. 2014, 2, 35-48. 
66. Taye, A.A. Caring for the Land: Best Practices in Soil and Water Conservation in Beressa Watershed, Highlands of Ethiopia. Ph.D. Thesis, Wageningen University, Wageningen, Olanda, 5 September 2006.

67. Mohammed, G.; Yan, D.; Wang, H.; Basaznew, A.M.C. Determinant Factors Affecting Crop Production and Adoption of Soil and Water Conservation Practices In Semein Mountain National Park, Ethiopia. Int. J. Environ. Sci. Resour. 2018, 13, 1-5.

68. Brück, T. Investment in Land, Tenure Security and Area Farmed in Northern Mozambique; University of Sussex: Brighton, UK, 2003; pp. 1-26.

69. Bekele, W. Economics of Soil and Water Conservation Theory and Empirical Application to Subsistence Farming in the Eastern Ethiopian Highlands. Ph.D. Thesis, Swedish University of Agricultural Sciences, Uppsala, Swedish, 2003.

70. Shiferaw, B.A.; Okello, J.; Reddy, R.V. Adoption and adaptation of natural resource management innovations in smallholder agriculture: Reflections on key lessons and best practices. Environ. Dev. Sustain. 2009, 11, 601-619. [CrossRef]

71. Abebe, Z.D.; Sewnet, M.A. Adoption of soil conservation practices in North Achefer District, Northwest Ethiopia. Chin. J. Popul. Resour. Environ. 2014, 12, 261-268. [CrossRef]

72. Asfaw, D.; Neka, M. Factors affecting adoption of soil and water conservation practices: The case of Wereillu Woreda (District), South Wollo Zone, Amhara Region, Ethiopia. Int. Soil Water Conserv. Res. 2017, 5, $273-279$. [CrossRef]

73. Holden, S.; Shiferaw, B.; Pender, J. Policy Analysis for Sustainable Land Management and Food Security in Ethiopia: A Bioeconomic Model with Market Imperfections; International Food Policy Research Institute: Washington, DC, USA, 2005; pp. 1-86.

74. Meseret, D. Determinants of Farmers' Perception of soil and water Conservation Practices on Cultivated Land in Ankesha District, Ethiopia. Agric. Sci. Eng. Technol. Res. 2014, 2, 1-9.

75. Rezvanfar, A.; Samiee, A.; Faham, E. Analysis of Factors Affecting Adoption of Sustainable Soil Conservation Practices among Wheat Growers. World Appl. Sci. J. 2009, 6, 644-651.

76. Mengstie, F.A. Assessment of Adoption Behavior of Soil and Water Conservation Practices in the Koga Watershed, Highlands of Ethiopia. Ph.D. Thesis, Faculty of the Graduate School of Cornell University, New York, NY, USA, 2009.

Publisher's Note: MDPI stays neutral with regard to jurisdictional claims in published maps and institutional affiliations.

(C) 2020 by the authors. Licensee MDPI, Basel, Switzerland. This article is an open access article distributed under the terms and conditions of the Creative Commons Attribution (CC BY) license (http://creativecommons.org/licenses/by/4.0/). 